\title{
Customer Engagement Behaviour in Social Media Advertising: Antecedents and Consequences
}

\author{
I Ping Chiang \\ National Taipei University \\ E-Mail: ntpu.im.iplab@gmail.com \\ Shih Hui Lo \\ National Taipei University \\ E-Mail: shihhuei40@gmail.com \\ Ling-Hui Wang \\ National Taipei University \\ E-Mail: betty1010177@gmail.com
}

\begin{abstract}
With the rapid growth and development of social network services, companies have largely increased their advertising budgets for social media advertising. Social media advertising has attracted a great deal of attention among marketers and researchers. However, very few works of research have focused on social media advertising and have only concentrated on measuring clicking effects. This study established a model to analyze customers' engagement in social media advertising, the relationship among the antecedents of social media advertising engagement, the engagement behaviours in social media advertising, and the consequences of social media advertising. This study conducted an online survey among 502 valid Internet users. Partial least squares regression was used to analyze the relationship among the antecedents and consequences of user engagement in social media advertising. Finally, based on the findings, discussions and conclusions will be provided regarding further research and practices.
\end{abstract}

Keywords: Social Media Marketing, Social Media Advertising, Customer Engagement Behaviour 


\section{INTRODUCTION}

In recent years, advances in technology and the prevalence of the Internet have resulted in the rapid development of social media. According to the 2013 statistics for eMarketer (2013), a quarter of the total global population uses social networking sites, and this number is expected to reach 2.55 billion people in 2017. This indicates that social networking sites are widely used and that their influence should not be underestimated. According to BIA/Kelsey, the amount of money invested in community advertising in the United States was US\$6.8 billion in 2014, and this amount was projected to increase to US\$9.2 billion in 2016. Social media advertising has become a focal topic in social marketing, and it plays an increasingly vital role in corporate marketing.

With the emergence of social media websites, firms and corporations have drastically increased their investments in social media advertising, thus indicating its significance in their success. Previous studies have investigated the influence of media advertising, including consumers' acceptance of social media advertising (Taylor et al. 2011) as well as the effects of social media advertising on consumers' decision-making process (Nyekwere et al. 2013). The preceding observations indicate that previous studies on social media advertising have focused on the conventional effects of Internet advertising; however, few studies have discussed consumer engagement behaviour in Internet advertising and its consequences.

The current study developed a model to explore the antecedents of consumer engagement behaviour in social media advertising and the consequences of such behaviour on the social community member relationship, product relationship, and brand relationship. Therefore, the objectives of this study are outlined as follows:

1. To explore the antecedents of consumer social media advertising engagement and the value generated from such engagement.

2. To confirm the constructs of the antecedents of social media advertising engagement in this study by using factor analysis.

3. To investigate the causal relationship between the antecedents of engagement in social media advertising and consumer engagement behaviour in such advertising as well as to explore the social community member relationship, product relationship, and brand relationship derived from such behaviour.

4. To generalize the empirical results of this analysis and provide suggestions and conclusions related to social media advertising marketing as a reference for future corporate social marketing strategies and academic studies. 


\section{THEORETICAL BACKGROUND}

\section{Social Media Advertising}

Because of the emergence of community and media-sharing websites and the gradual development of website-based community networks, social media users have begun to use these platforms for value creation and information exchange (Al-Debei et al., 2013). On Facebook, for example, users can retrieve information by browsing through the 'About', 'Status', and 'Photo' sections and ultimately develop friendships with other users (Luarn et al., 2014). Goyal (2013) described how social media advertising, which involves placing advertising messages on social media websites, yields maximum profits by accessing user information and then displaying specific advertising messages for target audiences. Khanfar et al. (2010) found that advertisers who apply customer marketing through social media advertising create more favourable relationships between brands and customers.

\section{Antecedents of User Engagement in Social Media Advertising}

When the valence and effects of social media advertising are measured, user response and acceptance on social media platforms can be determined. The attitudes of social media users towards advertising are affected by the expressed attitudes of other members within the social community (Zeng et al., 2013). According to Ducoffe (1996), users browsing online advertising messages generate perceptions towards such messages; such perceptions can be used to measure the value and effect of the advertising perceptions. Aaker (1990) and Ducoffe (1996) have both asserted that informativeness and the degree of entertainment are major indices for measuring the value of advertising. Additionally, Brackett and Carr (2001) mentioned credibility as another index for measuring perceptions towards advertising, and Wu (1999) added the index of interactivity to this discussion. On the basis of the described research, the current study measured the antecedents of consumer engagement behaviour in social media advertising using seven measures: social capital, social ties, social influence, informativeness, entertainment, credibility, and interactivity. As follows, we discuss each of these measures and their significance in the context of social media advertising.

\section{- Social Capital}

Jacobs (1961) pioneered the concept of social capital, which is established through relationship networks and the resources of personal or social networks, in which interaction and knowledge sharing have different effects (Nahapiet \& Ghoshal, 1998). And individual behavior mainly from the social network, Through frequent so- 
cial interaction can enhance the depth, breadth and efficiency of knowledge exchange (Bandura, 1989; Nahapiet \& Ghoshal, 1998). Chow and Chan (2008) found that social capital increases users' motivation to participate in knowledge sharing. On the basis of previous studies that have focused on social media activity and social capital, one can suggest that social media platforms are the only tool for promoting social capital (Ellison et al., 2007; Koh et al., 2010). We therefore proposed the following hypotheses:

$\mathrm{H}_{1}$ : Perceived social capital enhances user engagement behaviour related to social media advertising.

$\mathrm{H}_{1 \mathrm{a}}$ : Perceived social capital enhances sharing behaviour related to social media advertising.

$\mathrm{H}_{1 \mathrm{~b}}$ : Perceived social capital enhances commenting behaviour related to social media advertising.

$\mathrm{H}_{1 \mathrm{c}}$ : Perceived social capital enhances the creation of behaviour related to social media advertising.

- Social Influence

Previous literature has explained the intentional social behaviour of the social community user on the platform and the attitude and behavioural changes that arise when it occurs at different levels (Kelman, 1958). When users interact with others on the platform, they share value and targets; more interaction with other users would result in continuous use of the platform (Dholakia et al., 2004; Cheung \& Lee, 2010; Cheung et al., 2011). On the basis of the described research can inference, social Influence can regard us one's behavior and thinking were influenced by community members' values and thinking. Thus, the following hypotheses are proposed :

$\mathrm{H}_{2}$ : Perceived social influence enhances user engagement behaviour related to social media advertising.

$\mathrm{H}_{2 \mathrm{a}}$ : Perceived social influence enhances sharing behaviour related to social media advertising.

$\mathrm{H}_{2 b}$ : Perceived social influence enhances commenting behaviour related to social media advertising.

$\mathrm{H}_{2 \mathrm{c}}$ : Perceived social influence enhances creating behaviour related to social media advertising. 
- Social Tie

On social networks, social media users can interact with other users and affect each other by sharing information, thoughts, and views of a product or service (Centola, 2010; Wang and Chang, 2013). Intentional information gathering and sharing behaviour enhances the connection between users (Marsh et al., 2009). Social ties usually increase the self-worthiness by stimulating social relationships, and the relationship has a positive effect on creating content among users (Cheung et al., 2011; Shriver et al., 2013). Thus, we propose the following hypotheses:

$\mathrm{H}_{3}$ : Perceived social ties enhance user engagement behaviour related to social media advertising.

$\mathrm{H}_{3 \mathrm{a}}$ : Perceived social tie enhances sharing behaviour related to social media advertising.

$\mathrm{H}_{3 \mathrm{~b}}$ : Perceived social influence enhances commenting behaviour related to social media advertising.

$\mathrm{H}_{3 \mathrm{c}}$ : Perceived social influence enhances creating behaviour related to social media advertising.

- Entertainment

Ducoffe (1996) found that entertainment directly affects user attitudes towards advertising: A favourable advertising message not only positively affects user attitude towards the advertising but also increases user brand attitude. Users perceiving advertising to be entertaining demonstrate more engagement behaviour and exhibit positive attitudes towards the brand (Mir, 2011; Ünal et al., 2011). Therefore, we proposed the following hypotheses:

$\mathrm{H}_{4}$ : Perceived entertainment enhances user engagement behaviour related to social media advertising.

$\mathrm{H}_{4 \mathrm{a}}$ : Perceived entertainment enhances sharing behaviour related to social media advertising.

$\mathrm{H}_{4 \mathrm{~b}}$ : Perceived entertainment enhances commenting behaviour related to social media advertising.

$\mathrm{H}_{4 \mathrm{c}}$ : Perceived entertainment enhances creating behaviour related to social media advertising.

- Informativeness

Ducoffe (1996) found that informativeness in advertising could affect customers' 
satisfaction and purchase intention. Li-Ming et al. (2013) suggested that the information provided in the content of the advertising affects the attitude of the user towards the advertising. Informativeness is defined as the integrity and applicability of the information presented, and when the information delivered to customer in the advertising is rich, it enhances the positive effect towards the advertising. (Haida \& Rahim, 2015). Thus we propose the following hypotheses:

$\mathrm{H}_{5}$ : Perceived informativeness enhances user engagement behaviour related to social media advertising.

$\mathrm{H}_{5 \mathrm{a}}$ : Perceived informativeness enhances sharing behaviour related to social media advertising.

$\mathrm{H}_{5 \mathrm{~b}}$ : Perceived informativeness enhances commenting behaviour related to social media advertising.

$\mathrm{H}_{5 \mathrm{c}}$ : Perceived informativeness enhances creating behaviour related to social media advertising.

- Credibility

Brackett and Carr (2001) defined credibility as the content and source of advertising that affects customers' trust. Marshall and Woon (2003) pointed out that, when the content or source of the advertising fails to motivate the customer to trust, it decreases the attention of the user towards the advertising, even if the source and content are credible (Ünal et al., 2011; Chandra et al., 2013). Thus, we propose the following hypotheses:

$\mathrm{H}_{6}$ : Perceived credibility enhances user engagement behaviour related to social media advertising.

$\mathrm{H}_{6 \mathrm{a}}$ : Perceived credibility enhances sharing behaviour related to social media advertising.

$\mathrm{H}_{6 \mathrm{~b}}$ : Perceived credibility enhances commenting behaviour related to social media advertising.

$\mathrm{H}_{6 c}$ : Perceived credibility enhances creating behaviour related to social media advertising.

- Interactivity

Interactivity refers to a connection relationship through which an individual experiences sympathetic resonance toward the experience or thoughts shared by others (Zhao \& Lu, 2012). Furthermore, it includes a connection through which an individual 
shares similar characteristics with others, like the same interest or preferences, and greater connection might result in greater influence on each other (Ayeh et al., 2012). If the presented content of the advertising is similar to the interest of the user, it raises the attention of the user towards the advertising (Zhang and Wang, 2005). Thus we propose the following hypotheses:

$\mathrm{H}_{7}$ : Perceived interactivity enhances user engagement behaviour related to social media advertising.

$\mathrm{H}_{7 \mathrm{a}}$ : Perceived interactivity enhances sharing behaviour related to social media advertising.

$\mathrm{H}_{7 \mathrm{~b}}$ : Perceived interactivity enhances commenting behaviour related to social media advertising.

$\mathrm{H}_{7 \mathrm{c}}$ : Perceived interactivity enhances creating behaviour related to social media advertising.

\section{Engagement Behaviour in Social Media Advertising}

Zaglia (2013) described several antecedents of user engagement in social media communities: Some users search for knowledge related to the product being advertised, and some users join a social media platform upon recommendation by friends. Users interact with the content of social media platforms by sharing photos, videos, and links or replying to related articles. Habibi et al. (2014) indicated that a high degree of engagement behaviour in social media advertising results in positive effects. However, the literature offers only vague categories for engagement behaviour. Strauss and Frost (2014) proposed that engagement behaviour is generated when social media users start to discuss the brands in which they are interested.

- Sharing Behaviour

Brodie et al. (2013) stated that users share personal information, thoughts, and professional experience to contribute to knowledge creation in virtual communities. Kim et al. (2013) elaborated that social media users not only propose questions and seek answers regarding products but also share their thoughts about brands.

- Commenting Behaviour

User would give feedback or comment on the brand or product through various ways, for instance email or phone call, or assign a score to a certain product or brand on a social media platform (Zhao \& Dholakia, 2009; Muntinga et al., 2011). When customers are satisfied by the product or service, they give positive comments and 
spread information about it, and vice versa (Von Hippel, 2007).

- Creating Behaviour

Users create new content from the specific product or brand (Evans, 2010; Bernoff and Li, 2008). Strauss and Frost (2014) suggested that creating refers to editing or updating the existing content or creating new content or products for a company.

\section{Consequences of User Engagement in Social Media Advertising}

According to Berry (1983), relationship marketing in the service industry refers to the firm's ability to enhance and maintain the relationship with a single customer. Berry (1995) emphasized that relationship marketing can attract, maintain, and enhance long-term relationships instead of personal interaction. Previous literature has measured the brand effect of social community on the aspect of relationship marketing; such research suggests that, when the consumer spontaneously exchanges and shares thoughts, it helps to improve the quality of the product or service.

- Social Community Member Relationship

Cheung and Lee (2009) mentioned that social media advertising engagement in the context of virtual community results in increased identity and acceptance and thus the generation of value. Hoyer et al (2010) also mentioned that the value created from users' engagement behaviour ultimately enhances the relationship among the members. When the level of engagement in the social community is higher, it enhances users' satisfactory level, trust, relationship loyalty, and cohesion towards the community (Brodie et al., 2013). Therefore, the current study proposed the following hypotheses:

$\mathrm{H}_{8}$ : Users' engagement behaviours related to social media advertising enhance relationships among members of social media communities.

$\mathrm{H}_{8 \mathrm{a}}$ : Sharing behaviour related to social media advertising enhances relationships among members of social media communities.

$\mathrm{H}_{8 \mathrm{~b}}$ : Commenting behaviour related to social media advertising enhances relationships among members of social media communities.

$\mathrm{H}_{8 \mathrm{c}}$ : Creating behaviour related to social media advertising enhances relationships among members of social media communities.

- Product relationship

Thompsion and Sinha (2008) pointed out that consumers who participate in 
community activity demonstrate product preference and increased product acceptance. Shevlin (2007) suggested that the greater the customer's engagement frequency and repetitability, the more relationship attachment is generated. Amorim et al. (2014) also indicated that customer engagement behaviour might increase customer satisfaction. Thus, we propose the following hypotheses.

$\mathrm{H}_{9}$ : Users' engagement behaviours related to social media advertising enhance product relationships.

$\mathrm{H}_{9 \mathrm{a}}$ : Sharing behaviour related to social media advertising enhances product relationships.

$\mathrm{H}_{9 \mathrm{~b}}$ : Commenting behaviour related to social media advertising enhances product relationships.

$\mathrm{H}_{9 \mathrm{c}}$ : Creating behaviour related to social media advertising enhances product relationships.

- Brand relationship

Jang et al. (2008) stated that, when interaction and reciprocative behaviour are frequent, they help to enhance consumers' perception of brand relationship and the value attached to the brand, thus increasing their brand loyalty. Brodie et al. (2013) also mentioned that consumer engagement behaviour results in enhancing brand loyalty, satisfaction, relationship attachment, and trust. Thus, we propose the following hypotheses:

$\mathrm{H}_{10}$ : Users' engagement behaviours related social media advertising enhance brand relationships.

$\mathrm{H}_{10 \mathrm{a}}$ : Sharing behaviour related to social media advertising enhances brand relationships.

$\mathrm{H}_{10 \mathrm{~b}}$ : Commenting behaviour related to social media advertising enhances brand relationships.

$\mathrm{H}_{10 \mathrm{c}}$ : Creating behaviour related to social media advertising enhances brand relationships.

\section{METHODOLOGY}

\section{Conceptual Framework and Measures}

The questionnaires of this research were developed based on previous literature, in which a 3-stage model measurement which consists of 47 questions was presented 
to observe the social media advertising engagement. We adopted a six-point Likert scale ranging from 1 (strongly disagree) to 6 (strongly agree) and examined frequent users of Facebook as our target of observation to explore the impact of social media advertising engagement behaviour towards the user.

Based on the theoretical background, Figure 1 presents the conceptual framework.

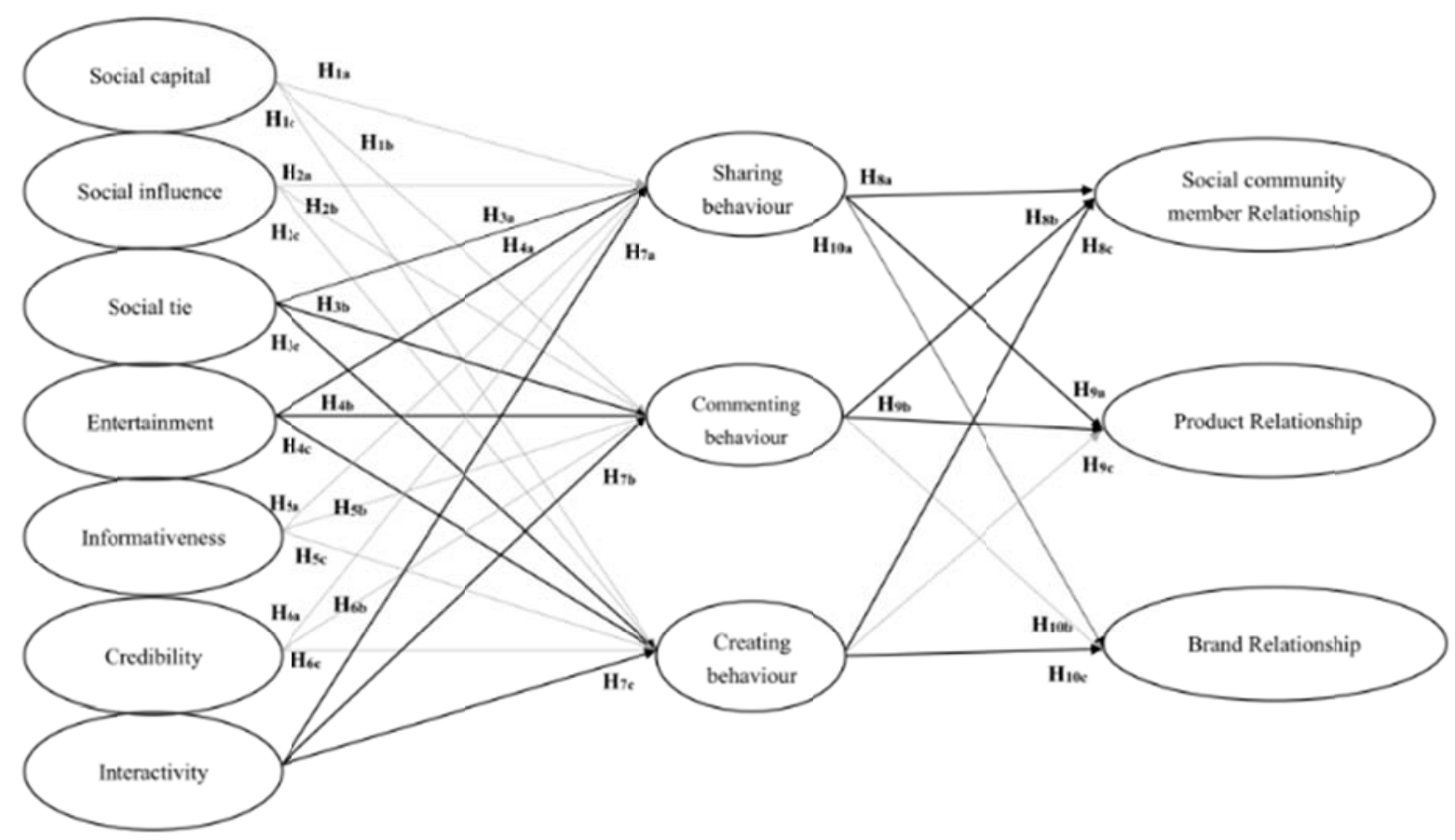

Figure 1 Conceptual Framework

\section{Data Collection}

This research was conducted through online survey, using InsightXplorer Cyberpanel system to collect the samples. 502 valid questionnaires were collected from participants. The profile of qualified samples is shown in Table 1. Furthermore, we specified the brands to distribute the questionnaires; Uniqlo represnted 53.4\% of the sample, while the participants discussing Lativ consisted of $46.6 \%$. To ensure that the questionnaire was applicable to Internet users, we used a structured sample with gender and age proportions representative of the Internet user population according to a report published by the Taiwan Network Information Center. Therefore, the overall structure of the samples collected was similar, and thus, there was no significant difference in the constructs between the samples of two brands as individual sample examination. Hence, we combined the samples to conduct further analysis. 
Table 1 Sample Profile

\begin{tabular}{lll}
\hline Gender & Total frequency & Proportion \\
\hline Male & 224 & $44.6 \%$ \\
\hline Female & 278 & $55.4 \%$ \\
\hline Age (years) & Total frequency & Proportion \\
\hline $20-24$ & 55 & $11.0 \%$ \\
\hline $25-29$ & 108 & $21.5 \%$ \\
\hline $30-34$ & 119 & $23.7 \%$ \\
\hline $35-39$ & 125 & $24.9 \%$ \\
\hline$>40$ & 95 & $18.9 \%$
\end{tabular}

\section{Credibility and Validity}

To assess the internal consistency of the constructs, we calculated Cronbach's $\alpha$, composite reliabilities (CR), and average variance extracted (AVE) for all constructs. According to Cooper and Schindler (2003), if the value of Cronbach's $\alpha$ in each construct was higher than 0.7 , then the construct has passed the minimum criteria of credibility. The overall credibility of this questionnaire among each constructs was higher than 0.7 , indicating that the constructs of this research has high credibility, as shown in Table 2.

Confirmatory Factor Analysis (CFA) was conducted to extract the factors. Regarding the criteria for validity analysis, Fornell and Larcker (1981) suggested that the criteria for validity needs to fit three criteria. Firstly, the factor loadings should be larger than 0.5 , and the CR needs to be 0.7 or above. Lastly, the AVE needs to be higher than 0.5. According the results of the analysis, the factor loadings, CR, and AVE of this research were all higher than $0.5,0.8$, and 0.5 respectively, indicating that the constructs of this research were valid.

\section{Procedure}

This study conducted Smart PLS 3.0 to assess the structural model evaluation, to examine the parameter estimation and the causal relationship between each constructs of the overall model, and to examine the hypotheses. 
Table 2 Credibility Analysis

\begin{tabular}{ll}
\hline Constructs & Cronbach's $\alpha$ \\
\hline Social capital & 0.785 \\
\hline Social Influence & 0.871 \\
\hline Social Tie & 0.890 \\
\hline Entertainment & 0.872 \\
\hline Informativeness & 0.844 \\
\hline Credibility & 0.915 \\
\hline Interactivity & 0.915 \\
\hline Sharing behaviour & 0.873 \\
\hline Commenting behaviour & 0.887 \\
\hline Creating behaviour & 0.914 \\
\hline Social member relationship & 0.941 \\
\hline Product relationship & 0.896 \\
\hline Brand relationship & 0.894 \\
\hline
\end{tabular}

\section{FINDINGS}

\section{Data Analysis}

On the basis of the described research, to validate a PLS path model on the hypthetical model, attention to the relationship between antecedents of user engagement in social media advertising, engagement behaviour in social media advertising, and cosequences of user engagement in social media advertising; The path analysis results of the overall model are shown in Figure 2.

Based on the results, first of all, when the perceived social capital within the social media website of the user was higher, it did not enhance the social media advertising sharing behaviour $\left(\beta_{1 \mathrm{a}}=-0.001, \mathrm{t}=0.027, \mathrm{p}>0.05\right)$, commenting behaviour $\left(\beta_{1 b}=-0.057, \mathrm{t}=1.064, \mathrm{p}>0.05\right)$, and creating behaviour $\left(\beta_{1 \mathrm{c}}=-0.066, \mathrm{t}=1.200, \mathrm{p}>0.05\right)$ among the users, hence $\mathrm{H}_{1 \mathrm{a}}, \mathrm{H}_{1 \mathrm{~b}}$, and $\mathrm{H}_{1 \mathrm{c}}$ were not supported. When the user's perceived social influence within the social media was higher, it would not enhance the user's likelihood to demonstrate sharing behaviour $\left(\beta_{2 \mathrm{a}}=0.072, \mathrm{t}=1.416, \mathrm{p}>0.05\right)$, commenting behaviour $\left(\beta_{2 b}=0.076, \mathrm{t}=1.357, \mathrm{p}>0.05\right)$, and creating behaviour $\left(\beta_{2 \mathrm{c}}=0.117, \mathrm{t}=1.948, \mathrm{p}>0.05\right)$ towards the social media advertising. Thus, $\mathrm{H}_{2 \mathrm{a}}, \mathrm{H}_{2 \mathrm{~b}}$, and $\mathrm{H}_{2 \mathrm{c}}$ were not supported. When the perceived social connection within the social media website of the user was higher, it motivated the user to generate sharing behaviour $\left(\beta_{3 \mathrm{a}}\right.$ $=0.259, \mathrm{t}=4.240, \mathrm{p}<0.001)$, commenting behaviour $\left(\beta_{3 \mathrm{~b}}=0.271, \mathrm{t}=3.877, \mathrm{p}<0.001\right)$, 
and creating behaviour $\left(\beta_{3 c}=0.282, t=4.311, \mathrm{p}<0.001\right)$; hence $\mathrm{H}_{3 \mathrm{a}}, \mathrm{H}_{3 \mathrm{~b}}$, and $\mathrm{H}_{3 \mathrm{c}}$ were supported.

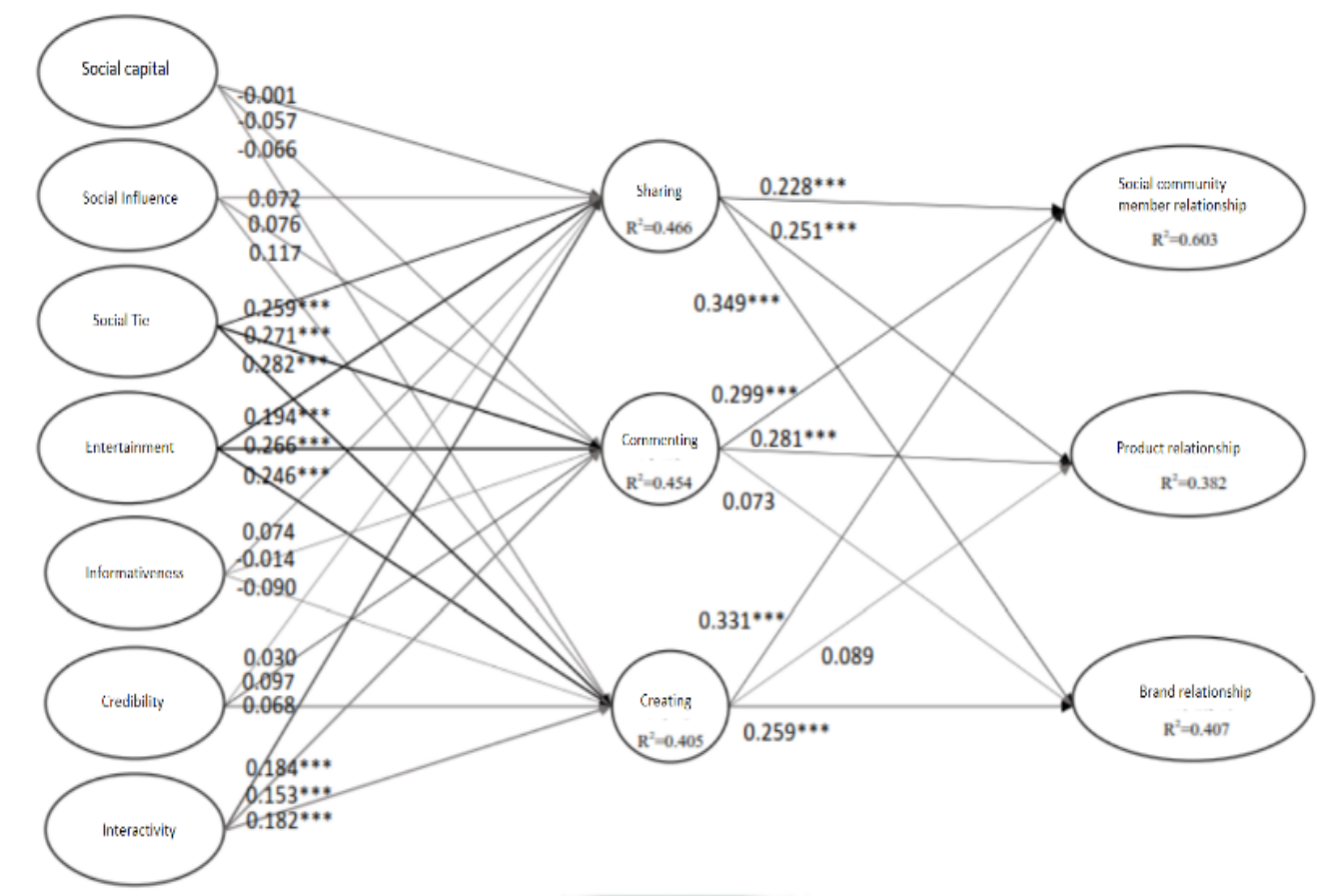

辣 : ***: $\mathrm{p}<0.001(1>3.29)$

Figure 2 PLS Model Analysis Result

Secondly, when the perceived entertainment towards the social media advertising among the users was higher, it enhanced the sharing behaviour $\left(\beta_{4 \mathrm{a}}=0.194, \mathrm{t}=4.129\right.$, $\mathrm{p}<0.001)$, commenting behaviour $\left(\beta_{4 \mathrm{~b}}=0.266, \mathrm{t}=5.259, \mathrm{p}<0.001\right)$, and creating behaviour $\left(\beta_{4 \mathrm{c}}=0.246, \mathrm{t}=4.913, \mathrm{p}<0.001\right)$; therefore, $\mathrm{H}_{4 \mathrm{a}}, \mathrm{H}_{4 \mathrm{~b}}$, and $\mathrm{H}_{4 \mathrm{c}}$ were supported. However, when the perceived information towards the social media advertising among the users was higher, it did not enhance the sharing behaviour $\left(\beta_{5 \mathrm{a}}=0.074, \mathrm{t}=1.474\right.$, $\mathrm{p}>0.05)$, commenting behaviour $\left(\beta_{5 \mathrm{~b}}=-0.014, \mathrm{t}=0.274, \mathrm{p}>0.05\right)$, and creating behaviour $\left(\beta_{5 \mathrm{c}}=-0.090, \mathrm{t}=1.495, \mathrm{p}>0.05\right)$ among the users; therefore $\mathrm{H}_{5 \mathrm{a}}, \mathrm{H}_{5 \mathrm{~b}}$, and $\mathrm{H}_{5 \mathrm{c}}$ were not supported. When the perceived credibility towards the social media advertising among the users was higher, it did not enhance sharing behaviour $\left(\beta_{6 \mathrm{a}}=0.030, \mathrm{t}=0.553\right.$, $\mathrm{p}>0.05)$, commenting behaviour $\left(\beta_{6 b}=0.097, \mathrm{t}=1.745, \mathrm{p}>0.05\right)$, and creating behaviour $\left(\beta_{6 c}=0.068, \mathrm{t}=1.280, \mathrm{p}>0.05\right)$; thus $\mathrm{H}_{6 \mathrm{a}}, \mathrm{H}_{6 \mathrm{~b}}$, and $\mathrm{H}_{6 \mathrm{c}}$ were not supported. When the perceived interactivity towards the social media advertising among the users was higher, it enhanced the sharing behaviour $\left(\beta_{7 \mathrm{a}}=0.184, \mathrm{t}=4.308, \mathrm{p}<0.001\right)$, commenting behaviour $\left(\beta_{7 \mathrm{~b}}=0.153, \mathrm{t}=3.301 \mathrm{p}<0.001\right)$, and creating behaviour $\left(\beta_{7 \mathrm{c}}=0.182, \mathrm{t}=4.308\right.$, $\mathrm{p}<0.001$ ); therefore, $\mathrm{H}_{7 \mathrm{a}}, \mathrm{H}_{7 \mathrm{~b}}$, and $\mathrm{H}_{7 \mathrm{c}}$ were supported. 
Based on the results, we further discussed the impact of social media advertising engagement behaviour on the social media advertising effect. The analysis results indicated that, when the sharing behaviour $\left(\beta_{8 \mathrm{a}}=0.228, \mathrm{t}=3.887, \mathrm{p}<0.001\right)$, commenting behaviour $\left(\beta_{8 \mathrm{~b}}=0.251, \mathrm{t}=3.806, \mathrm{p}<0.001\right)$ and creating behaviour $\left(\beta_{8 \mathrm{c}}=0.349, \mathrm{t}=5.757\right.$, $\mathrm{p}<0.001)$ related to social media advertising are higher, they enhance more relationships among members of social media communities. Therefore, $\mathrm{H}_{8 \mathrm{a}}, \mathrm{H}_{8 \mathrm{~b}}, \mathrm{H}_{8 \mathrm{c}}$ were supported. When the sharing behaviour $\left(\beta_{9 \mathrm{a}}=0.299, \mathrm{t}=4.706, \mathrm{p}<0.001\right)$ and commenting behaviour $\left(\beta_{9 \mathrm{~b}}=0.281, \mathrm{t}=3.516 \mathrm{p}<0.001\right)$ related to social media advertising are higher, they enhance the product relationship and creating behaviour $\left(\beta_{9 \mathrm{c}}=0.073\right.$, $\mathrm{t}=1.092, \mathrm{p}>0.05)$, without enhancing the product relationship. Thus, $\mathrm{H}_{9 \mathrm{a}}$ and $\mathrm{H}_{9 \mathrm{~b}}$ were supported, and $\mathrm{H}_{9 \mathrm{c}}$ was not supported. When the sharing behaviour $\left(\beta_{10 \mathrm{a}}=0.331\right.$, $\mathrm{t}=4.439, \mathrm{p}<0.001)$ and creating behaviour $\left(\beta_{10 \mathrm{c}}=0.259, \mathrm{t}=3.939 \mathrm{p}<0.001\right)$ related to social media advertising are higher, they enhance the brand relationship and commenting behaviour $\left(\beta_{10 \mathrm{~b}}=0.089, \mathrm{t}=1.106, \mathrm{p}>0.05\right)$, without enhancing the brand relationship; thus, $\mathrm{H}_{10 \mathrm{a}}$ and $\mathrm{H}_{10 \mathrm{c}}$ were supported, and $\mathrm{H}_{10 \mathrm{~b}}$ was not supported.

\section{Discussions}

The objective of this study is to examine customer engagement related to social media advertising. First, we discuss the antecedents, namely social capital, social influence, and social ties, and their influence on users' engagement behaviour in social media advertising, including sharing, commenting, and creating behaviour. According to the empirical results, social capital and social influence were nonsignificant in enhancing user engagement in the social media advertising. By contrast, social ties were mainly responsible for the enhanced engagement of users in social media advertising. We infer that the degree of user activity enhances user engagement in social media advertising, indicating that the uniqueness of a social media platform causes social ties to significantly enhance user engagement in social media advertising; this inference is similar to the arguments of Cheung et al. (2011) and Shriver et al. (2013). However, as mentioned, social capital and social influence did not have a significant effect on the enhancement of users' engagement in social media advertising; therefore, we infer that a low level of interaction between a user and other members on a social media platform or a distant relationship between them prevents the users's engagement in social media advertising.

Furthermore, the informational degree or credibility of advertising did not significantly affect users' engagement behaviour. However, the interactivity and level of entertainment of advertising exerted significant effects on users' engagement. Therefore, considering the design of social media advertising, users perceiving advertising 
to be entertaining and interactive exhibited more significant engagement behaviour, compared with those who perceived it to have a high informational degree and credibility; this finding is similar to those of Unal et al. (2011) and Ayeh et al. (2012). Moreover, the possible reason for the nonsignificant effect of the informational degree and credibility of social media advertising is that users possess a high level of perception toward its informational degree and credibility. Because this study selected well-known brands as subjects, the source of advertising was known and credible to the users, and the content of the designed social media advertising was related to apparel instead of experiential goods. The informational degree could not be the main reason for the user's engagement in social media advertising. Hence, the informational degree and credibility of social media advertising had nonsignificant effects on the enhancement of engagement behaviour.

Finally, we discuss the consequences of user engagement in the social media advertising through a path analysis. We found different effects on the various categories of engagement behaviour in social media advertising. Regarding the users' engagement behaviour in social media, advertising, sharing, commenting, and creating all strengthened the relationships among the social community members. Therefore, we infer that marketers should employ social marketing to strengthen the relationships among social community members, products, and brands to create relationship attachment, as suggested by Shevlin (2007), Khanfar et al. (2010), and Luarn et al. (2014).

Moreover, we investigated the influences of engagement behaviour in social media advertising on the product relationship. Sharing and commenting behaviour may enhance the relationship between users and products, thus indicating that the higher frequency of user engagement behaviour in social media advertising would create a stronger emotional connection, consistent with the findings of Shevlin (2007). Sharing and creating behaviour can strengthen the relationship between brands and users, which complements the research of Thompson and Sinha (2008). A higher degree of engagement within the social community would generate a specific emotional preference, thus enhancing acceptance and loyalty towards brands. Moreover, users' commenting behaviour did not have a significant effect on product relationship enhancement. We thus infer that users exhibit reduced preference towards a brand image that has negative comments or feedback. In addition, the creating behaviour of users had a nonsignificant effect on the relationship between users and the brands. Therefore, we rationalise that creating behaviour is related to a higher degree of engagement. Although most users on the social media platform were actively either sharing or commenting, such behaviour is less likely to create new services or products and exerts 
less significant effects on strengthening the product relationship.

\section{Conclusions and Suggestions}

On the basis of the study results, from the aspect of social community, social ties has the most significant effects among the antecedents influencing consumer engagement in social media advertising. This finding indicates that a higher level of interaction between a user and other social community members stimulates the exchange of information or thoughts. By contrast, in terms of advertising, entertainment level and interactivity exert a more significant effect. Social media advertising with a higher perceived entertainment level or a mutual connection with users increases the favourability of users towards advertising, thus increasing their attention and interest. According to these findings, among the seven antecedents affecting users' engagement behaviour in social media advertising, social ties, entertainment level, and interactivity have the most significant effects. Moreover, according to the consequences of users' engagement behaviour in social media advertising, sharing, commenting, and creating behaviour in social media advertising have significant effects on the enhancement of the relationship of the users with social community members, brands, and products. This finding indicates that more frequent consumer engagement in social media advertising represents that consumers have a specific emotional preference for the brands involved, thus increasing their satisfaction and connection with the brands and products, consequently resulting in positive effects.

This study contributes to the existing research in several ways. We found that, among the antecedents affecting users' engagement in social media advertising, social capital and social influence had nonsignificant effects. This could be because the brands used in this study comprised a generalised brand and a masstige brand. Users thus faced lower risk when purchasing such brands or a lower level of complexity in their purchase decisions. Therefore, social capital and social influence have nonsignificant effects on relationship enhancement. Future research should target apparel brands with higher price levels to generate different consequences.

Regarding the practical contribution of this study, we explored the consequences generated from social media advertising by measuring social media engagement behaviour. According to the research results, marketers and researchers should consider the following recommendations when designing social media advertising. First, during the design of social media advertising, marketers should focus on managing fan pages or social communities on online social platforms to increase the activity and connection between users and social community members or fan pages, thereby enhancing users' engagement behaviour. Moreover, because we reveal that the perceived infor- 
mational degree and credibility of advertising had nonsignificant effects, marketing personnel should focus on the level of entertainment and interactivity in advertising designs, enabling users to perceive the fun and novelty of advertising. Users' interests and purchasing preference are highly correlated; hence, enhancing such interests in advertising can stimulate users' engagement behaviour. In addition, according to the results of examining the consequences of users' engagement behaviour in the social media advertising, users' engagement behaviour may vary depending on their perceptions of social media advertising. Moreover, users' activity level in a social media community changes. This study selected the relatively well-known brands Uniqlo and Lativ, and the overall evaluation of these two brands was considered to be satisfactory, without many negative comments. Therefore, commenting behaviour had less significant effects on advertising. Future research should consider the fact that the valence of comments can influence the brand relationship. Moreover, marketing personnel can organise creation events focusing on the brands or products on the communities or fan pages to stimulate consumer engagement in the fan pages.

Finally, we describe the research limitations and propose recommendations for future research. The empirical results of this study are applicable only within the context of this study. The product category used in this study was apparel, and future research can examine a different product category to generate different engagement behaviour outcomes and effects. In addition, while Uniqlo and Lativ were selected as the main social media brands in this study, future research could select other brands to generate different social media advertising engagement behaviour outcomes induced by the difference in social media platform management and consumer perception towards the brands.

Furthermore, our research samples all comprised respondents from Taiwan. Future research can collect data on engagement in social media advertising from other countries; hence, the research result will become more representative of the general population. The results of the overall route analysis may vary across different cultures and community habits. Moreover, this study did not include negative measures in the model design. Future research could explore the negative causes of engagement in social media advertising (e.g. perceived social media advertising interference) and engagement behaviour in such advertising (negative commentary behaviour) to the extent of the related effects.

With regard to the mentioned research limitations and recommendations, we hope to provide a reference for future research on social media advertising and further explore the antecedents of consumer engagement behaviour in social media advertising to provide more comprehensive research. 


\section{REFERENCES}

Aaker, D. (1990), 'Brand extensions: The good, the bad, and the ugly', MIT Sloan Management Review, 31(4), 47.

Al-Debei, M. M., Al-Lozi, E., \& Papazafeiropoulou, A. (2013). Why people keep coming back to Facebook: Explaining and predicting continuance participation from an extended theory of planned behaviour perspective. Decision support systems, 55(1), 43-54. http://dx.doi.org/10.1016/j.dss.2012.12.032

Amorim, M., Rosa, M.J., \& Santos, S. (2014). Managing customer participation and customer interactions in service delivery: The case of museums and educational services. Organizacija, 47, 166-175. http://dx.doi.org/10.2478/orga-2014-0015

Ayeh, J. K., Au, N., \& Law, R. (2012). Predicting the intention to use consumer-generated media for travel planning. Tourism Management, 35(12), 132-143. http://dx.doi.org/10.1016/j.tourman.2012.06.010

Bandura, A. (1989), 'Social Cognitive Theory, Annals of Child Development', Jai Press LTD, Greenwich, CT, 1-60.

Bernoff, J., \& Li, C. (2008). Groundswell: Winning in a world transformed by social technologies. Boston: Harvard Business School Publishing.

Berry, L. L. (1983). Relationship Marketing, in Berry, L. L., Shostack, G. L. and Upah, G.D.(Eds), Emerging Perspective of ServicesMarketing. Chicago: American Marketing Association, 25-28.

Berry, L. L. (1995). Relationship marketing of services-growing interest, emerging perspectives. Journal of the Academy of marketing science, 23(4), 236-245.

BIA/Kelsey(2012), New BIA/Kelsey Report Emphasizes 'Localization' Opportunity for National Mobile Ad Campaigns, Retrieved June 20, 2016 from: http:/www.biakelsey.com/Company/Press-Releases/121126-U.S.-Social-MediaAd-Revenues-to-Grow-from-\%244.6B-in-2012-to-\%249.2B-in 2016.asp

Brackett, L. K., \& Carr, B. N. (2001). Cyberspace advertising vs. other media: Consumer vs. mature student attitudes. Journal of advertising research, 41(5), 23-32. http://dx.doi.org/10.2501/JAR-41-5-23-32

Brodie, R. J., Ilic, A., Juric, B., \& Hollebeek, L. (2013). Consumer engagement in a virtual brand community: An exploratory analysis. Journal of Business Research, 66(1), 105-114. http://dx.doi.org/10.1016/j.jbusres.2011.07.029

Centola, D. (2010). The spread of behaviour in an online social network experiment. Science, 329(5996), 1194-1197.

Chandra, B., Goswami, S., \& Chouhan, V. (2013). Investigation attitude towards online advertising on social media-An Empirical Study. Management Insight, $8(1), 1-14$. 
Cheung, C. M., \& Lee, M. K. (2009). Understanding the sustainability of a virtual community: Model development and empirical test. Journal of Information Science, 35(3), 279-298.

Cheung, C. M., \& Lee, M. K. (2010). A theoretical model of intentional social action in online social networks. Decision support systems, 49(1), 24-30.

Cheung, C. M., Chiu, P. Y., \& Lee, M. K. (2011). Online social networks: Why do students use facebook?. Computers in Human Behaviour, 27(4), 1337-1343. http://dx.doi.org/10.1016/j.chb.2010.07.028

Chow, W. S., \& Chan, L. S. (2008). Social network, social trust and shared goals in organizational knowledge sharing. Information \& Management, 45, 458-465. http://dx.doi.org/10.1016/j.im.2008.06.007

Cooper, D. R., \& Schindler, P. S. (2003). Business Research Methods (8 th edn.) McGrawHill: New York.

Dholakia, U. M., Bagozzi, R. P., \& Pearo, L. K. (2004). A social influence model of consumer participation in network-and small-group-based virtual communities. International Journal of Research in Marketing, 21(3), 241-263. http://dx.doi.org/10.1016/j.ijresmar.2003.12.004

Ducoffe, R. H., (1996). Advertising Value and Advertising on the Web. Journal of Advertising Research, 36(5), 21-35.

Ellison, N. B., Steinfield, C., \& Lampe, C. (2007). The benefits of Facebook "friends:" Social capital and college students' use of online social network sites. Journal of Computer-Mediated Communication, 12(4), 1143-1168.

eMarketer (2013), Social Networking Reaches Nearly One in Four Around the World, Retrieved June 20, 2016 from: http://www.emarketer.com/Article/Social-Networking-Reaches-Nearly-One-Four -Around-World/1009976

Evans, D. (2010). Social media marketing: the next generation of business engagement. John Wiley \& Sons.

Fornell, C.,Larcker, D. F.(1981), 'Evaluating structural equation models within observable variables and measurement error', Journa of Marketing Research, 18, $39-50$.

Goyal, S. (2013). Advertising on social media. Scientific Journal of Pure and Applied Sciences, 2(5), 220-223.

Habibi, M. R., Laroche, M., \& Richard, M. O. (2014). The roles of brand community and community engagement in building brand trust on social media.Computers in Human Behaviour, 37, 152-161. http://dx.doi.org/10.1016/j.chb.2014.04.016

Haida, A., \& Rahim, H. L. (2015). Social Media Advertising Value: A Study on Con- 
sumer's Perception. Technology, 1(1), 1-8.

Hoyer, W. D., Chandy, R., Dorotic, M., Krafft, M., \& Singh, S. S. (2010). Consumer cocreation in new product development. Journal of Service Research, 13(3), 283-296.

Jacobs, J. (1961). The death and life of great American cities. Random House LLC.

Jang, H., Olfman, L., Ko, I., Koh, J., \& Kim, K. (2008). The influence of on-line brand community characteristics on community commitment and brand loyalty. International Journal of Electronic Commerce, 12(3), 57-80. http://dx.doi.org/10.2753/JEC1086-4415120304

Kelman, H. C. (1958). Compliance, identification, and internalization three processes of attitude change. The Journal of Conflict Resolution, 2(1), 51-60.

Kim, H., Suh, K-S., \& Lee, U-K. (2013). Effects of collaborative online shopping on shopping experience through social and relational perspectives. Information \& Management, 50(4), 169-180. http://dx.doi.org/10.1016/j.im.2013.02.003

Koh, S. M., Hwang, B. H., \& Ji, Y. G. (2010). Social network service and online social capital: Cases of Korea and China. Journal of the Society for e-Business Studies, 15(1), 103-118.

Li-Ming, A. K., Wai, T. B., Hussin, M., \& Mat, N. K. N. (2013). The predictors of attitude towards online advertising. International Journal of Applied Psychology, 3(1), 7-12.

Luarn, P., Yang, J. C., \& Chiu, Y. P. (2014). The network effect on information dissemination on social network sites. Computers in Human Behaviour, 37, 1-8. http://dx.doi.org/10.1145/2441776.2441867

Marsh, K. L., Richardson, M. J., \& Schmidt, RC. (2009). Social connection through joint action and interpersonal coordination. Topics in Cognitive Science,1(2),320-339. http://dx.doi.org/10.1111/j.1756-8765.2009.01022.x

Marshall, R., \& WoonBong, N. (2003). An experimental study of the role of brand strength in the relationship between the medium of communication and perceived credibility of the message. Journal of Interactive Marketing, 17(3), 75-79. http://dx.doi.org/10.1002/dir.10061

Mir, I. (2011), 'Consumer Attitude Towards M-Advertising Acceptance: A Cross-Sectional Study', Journal of Internet Banking and Commerce, 16(1), 1-22.

Muntinga, D. G., Moorman, M., \& Smit, E. G. (2011). Introducing COBRAs: Exploring motivations for brand-related social media use. International Journal of Advertising, 30(1), 13-46. http://dx.doi.org/10.2501/IJA-30-1-013-046

Nahapiet, J., \& Ghoshal, S. (1998). Social capital, intellectual capital, and the organizational advantage. Academy of Management Review, 23(2), 242-266. 
http://dx.doi.org/10.5465/AMR.1998.533225Nyekwere, E. O., Kur, J. T., \& Nyekwere, O. (2013). Awareness and Use of Social Media in Advertising: The Case of Facebook among Residents of Port Harcourt, Nigeria. African Research Review, 7(4), 174-194. http://dx.doi.org/10.4314/afrrev.v7i4.11

Shevlin, Ron(January 2, 2007), Engagement Myopia, Retrieved June 20, 2016 from: http://marketingroi.wordpress.com/2007/01/02/engagement-myopia/

Shriver, S. K., Nair, H. S., \& Hofstetter, R. (2013). Social ties and user-generated content: Evidence from an online social network. Management Science, 59(6), 1425-1443. http://dx.doi.org/10.1287/mnsc.1110.1648

Strauss, J., \& Frost, R. (2014). E-marketing. Pearson Prentice Hall.

Thompson, S. A., \& Sinha, R. K. (2008). Brand communities and new product adoption: the influence and limits of oppositional loyalty. Journal of Marketing, 72(6), 65-80.

Ü nal, S., Ercis, A., \& Keser, E. (2011). Attitudes towards Mobile Advertising-A Research to Determine the Differences between the Attitudes of Youth and Adults. Procedia-Social and Behavioural Sciences, 24(32), 361-377.

Von Hippel, E. (2007). Horizontal innovation networks - by and for users. Industrial and corporate change, 16(2), 293-315.

Wang, J. C., \& Chang, C. H. (2013). How online social ties and product-related risks influence purchase intentions: A Facebook experiment. Electronic Commerce Research and Applications, 12(5), 337-346.

Wright, E., Khanfar, N. M., Harrington, C., \& Kizer, L. E. (2010), 'The lasting effects of social media trends on advertising', Journal of Business \& Economics Research, 8(11), 73-80. http://dx.doi.org/10.19030/jber.v8i11.50

Wu, G. (1999, March). Perceived interactivity and attitude toward web sites. In Proceedings of the conference-American Academy of Advertising. American Academy of Advertising. 254-262.

Zaglia, M. E. (2013). Brand communities embedded in social networks. Journal of business research, 66(2), 216-223. http://dx.doi.org/10.1016/j.jbusres.2012.07.015

Zeng, X., \& Wei, L. (2013), 'Social ties and user content generation: Evidence from Flickr', Information $\quad$ Systems $\quad$ Research, 24(1), http://dx.doi.org/10.1287/isre.1120.0464

Zhang, P. and Wang C. (2005, June). "An Empirical Study on Consumers Perceived Value and Attitudes toward Advertising", In Proceedings of the 6th Global Information Technology and Management (GITM) World Conference, Anchorage, Alaska.

Zhao, L., \& Lu, Y. (2012). Enhancing perceived interactivity through network exter- 
nalities: An empirical study on micro-blogging service satisfaction and continuance intention. Decision Support Systems, 53(4), 825-834. http://dx.doi.org/10.1016/j.dss.2012.05.019

Zhao, M., \& Dholakia, R.R. (2009). A multi-attribute model of web site interactivity and customer satisfaction: An application of the Kano model. Managing Service Quality, 19(3), 286-307. 


\section{APPENDIX}

\begin{tabular}{|c|c|c|}
\hline Constructs & Measurement Items & Source \\
\hline Social Capital & $\begin{array}{l}\text { The messages which send from Facebook members is } \\
\text { trustworthy. } \\
\text { Community members and I learn and share resources with } \\
\text { each other for common goals. } \\
\text { Compared with the other Social media, using Facebook can } \\
\text { find out what's going on with friends immediately. }\end{array}$ & $\begin{array}{l}\text { Chiu et al. } \\
\text { (2006) } \\
\text { Steinfield et al. } \\
\quad(2008)\end{array}$ \\
\hline $\begin{array}{l}\text { Social } \\
\text { Influence }\end{array}$ & $\begin{array}{l}\text { I pay attention to the opinions from Facebook members. } \\
\text { I pay attention to the interactions with Facebook members. } \\
\text { Friends on Facebook are very important to me. }\end{array}$ & $\begin{array}{l}\text { Tonteri et al. } \\
\text { (2011) } \\
\text { Richard et al. } \\
\quad(2010)\end{array}$ \\
\hline Social Tie & $\begin{array}{l}\text { I would have frequent communication with Facebook } \\
\text { members. } \\
\text { I really enjoy interacting with Facebook members. } \\
\text { Facebook members and I have same intersts/preferences. }\end{array}$ & $\begin{array}{l}\text { Abfalter et al. } \\
\text { (2012) } \\
\text { Wang et al. } \\
\text { (2012) }\end{array}$ \\
\hline Entertainment & $\begin{array}{l}\text { The content of social media advertising is attractive to me. } \\
\text { The content of social media advertising is interesting. } \\
\text { Social media advertising is fun. }\end{array}$ & $\begin{array}{l}\text { Chandra et al. } \\
\text { (2013) } \\
\text { Zhang \& Wang } \\
\text { (2005) }\end{array}$ \\
\hline Informativeness & $\begin{array}{l}\text { Social media advertising provide the information of prod- } \\
\text { uct. } \\
\text { Social media advertising provide the complete information } \\
\text { of product. } \\
\text { Social media advertising can let me know more about } \\
\text { product. }\end{array}$ & $\begin{array}{l}\text { Chandra et al. } \\
\text { (2013) } \\
\text { Adeline et al. } \\
\quad(2013) \\
\text { Zhang \& Wang } \\
\quad(2005)\end{array}$ \\
\hline Credibility & $\begin{array}{l}\text { The content of social media advertising is trustworthy. } \\
\text { The source of social media advertising is reliable. } \\
\text { The content of social media advertising is correct. }\end{array}$ & $\begin{array}{l}\text { Chandra et al. } \\
\text { (2013) } \\
\text { Zhang \& Wang } \\
\text { (2005) }\end{array}$ \\
\hline Interactivity & $\begin{array}{l}\text { The content of social media advertising is similar to my } \\
\text { interests. } \\
\text { Social media advertising can meet my demand. } \\
\text { The type of merchandise in the social media advertising is } \\
\text { similar to my purchase preference. }\end{array}$ & $\begin{array}{l}\text { Zhang, \& Wang } \\
\text { (2005) } \\
\text { Zhao et al. } \\
\text { (2012) }\end{array}$ \\
\hline $\begin{array}{l}\text { Sharing } \\
\text { behaviour }\end{array}$ & $\begin{array}{l}\text { I will share the link or information about the product on } \\
\text { facebook. } \\
\text { I will invite my friend click the Like button on this fan } \\
\text { page. } \\
\text { I will tag my friend with a message to share social media } \\
\text { advertising. } \\
\text { I will send pictures or related information of the product to } \\
\text { my friend by private message. }\end{array}$ & $\begin{array}{l}\text { Paek et al. } \\
\text { (2013) } \\
\text { Verhagen et al. } \\
\quad(2015)\end{array}$ \\
\hline
\end{tabular}




\begin{tabular}{|c|c|c|}
\hline Constructs & Measurement Items & Source \\
\hline $\begin{array}{l}\text { Commenting } \\
\text { behaviour }\end{array}$ & $\begin{array}{l}\text { I will respond to comments on my page/posts on my wall. } \\
\text { I will make comments in social media advertising post. } \\
\text { I will make comments on fan page. }\end{array}$ & $\begin{array}{l}\text { Tosun (2012) } \\
\text { Subrahmanyam } \\
\text { et al. (2008) } \\
\text { Zaglia(2013) }\end{array}$ \\
\hline $\begin{array}{l}\text { Creating } \\
\text { behaviour }\end{array}$ & $\begin{array}{l}\text { I will upload personal creative / feature experience to Fa- } \\
\text { cebook news feed. } \\
\text { I will invite other friends to create new topic/content about } \\
\text { this product. } \\
\text { I will record the skills of using the product as a film / ani- } \\
\text { mation } \\
\text { I will discuss with firms and provide suggestions about this } \\
\text { product. }\end{array}$ & $\begin{array}{l}\text { Brodie et al. } \\
\quad(2013) \\
\text { Spielmann \& } \\
\text { Richard(2013) } \\
\text { Strauss \& Frost } \\
\quad(2014)\end{array}$ \\
\hline $\begin{array}{l}\text { Social commu- } \\
\text { nity member } \\
\text { relationship }\end{array}$ & $\begin{array}{l}\text { I will discover new friend who has the same interests on } \\
\text { Fan page. } \\
\text { I identify myself to be a part of this Fan page. } \\
\text { I will be more often to discuss interesting things with com- } \\
\text { munity members of the fan page. } \\
\text { Interacting with members of the fan page, that will make } \\
\text { me more interested in this fans page. }\end{array}$ & $\begin{array}{l}\text { Habibi et al. } \\
\quad(2014) \\
\text { Zhang et al. } \\
\quad(2015) \\
\text { Abdul-Ghani et } \\
\text { al. (2011) }\end{array}$ \\
\hline $\begin{array}{l}\text { Product } \\
\text { relationship }\end{array}$ & $\begin{array}{l}\text { I pefer this product's texture rather than others. } \\
\text { I tend to buy the product of this series. } \\
\text { I think buying this product is worthy. } \\
\text { I would like to learn more about the specifications and ma- } \\
\text { terials of this product. } \\
\text { I would like to know more about the new information / new } \\
\text { activities of this product. }\end{array}$ & $\begin{array}{l}\text { Habibi et al. } \\
\text { (2014) } \\
\text { Zhang et al. } \\
\text { (2015) } \\
\text { Luo et al. } \\
\text { (2015) }\end{array}$ \\
\hline $\begin{array}{l}\text { Brand } \\
\text { relationship }\end{array}$ & $\begin{array}{l}\text { In the same type of products in the market, I will buy the } \\
\text { products of this brand. } \\
\text { When I want to buy particular product, this brand is one of } \\
\text { the brands that comes to my mind. } \\
\text { This brand is very meaningful to me. } \\
\text { I will buy all products which launch by this brand. }\end{array}$ & $\begin{array}{c}\text { Habibi et al. } \\
\text { (2014) } \\
\text { Luo et al. } \\
\text { (2015) } \\
\text { Cai et al. (2015) }\end{array}$ \\
\hline
\end{tabular}

